\title{
Biallelic LINE insertion mutation in HACD1 causing congenital myopathy
}

Fatema Al Amrani, MD, Carolina Gorodetsky, MD, Lili-Naz Hazrati, MD, Kimberly Amburgey, MSc, Hernan D. Gonorazky, MD, and James J. Dowling, MD, PhD

Neurol Genet 2020;6:e423. doi:10.1212/NXG.0000000000000423

Congenital myopathies are clinically and genetically heterogeneous, resulting from mutations in at least 30 different genes. ${ }^{1}$ The classical presentation is neonatal hypotonia and nonprogressive weakness with normal creatine phosphokinase, although there is a broad range in terms of age at onset and clinical presentation. Historically, congenital myopathies have been defined and diagnosed based on muscle biopsy. However, with advances in genomics, genetics have taken primacy in the diagnostic pathway. ${ }^{2}$

HACD1 encodes 3-hydroxyacyl-CoA dehydratase 1, which participates in the biosynthesis of very-long-chain fatty acids (VLCFAs). A single family with 8 affected members was previously described with homozygous nonsense mutation in HACD1. The clinical presentation included severe neonatal hypotonia and weakness, with impressive improvement through childhood and early adulthood. Muscle biopsy was consistent with congenital fiber-type disproportion. ${ }^{3}$

\section{Case report}

We present the second case of HACD1 myopathy. The affected individual underwent initial evaluation for hypotonia as a neonate. She is the second child of consanguineous (first cousin) parents of Sri Lankan descent. She was born by C-section at 35+2/7 weeks and noted to have hypotonia at birth. She had poor oral intake requiring nasogastric tube supplementation but no respiratory difficulties. Physical examination at age 19 days showed no dysmorphic features, normal cranial nerve examination, severe axial and appendicular hypotonia, and a nearcomplete absence of antigravity movements. Workup included brain MRI, chromosomal microarray, Prader-Willi testing, and metabolic screening laboratories and did not provide a diagnosis. Management was supportive, with occupational and physiotherapy and feeding assistance.

Neuromuscular consultation was solicited at age 4 years. At that time, she had proximal muscle weakness and mild gross motor delay. She had achieved ambulation, could do stairs without difficulty, and could ride a bike with training wheels. Her feeding difficulties had resolved. Physical examination revealed a long, myopathic facies but no clear facial weakness (figure, A), with normal eyelid strength and no restriction of eye movements. She had reduced muscle tone, hyperextensibility at the elbows, but no joint contractures. She had mild proximal extremity muscle weakness (Medical Research Council grade 4/5 at deltoid and hip flexors/extensors), a negative Gowers sign, and mild Trendelenburg gait and was unable to run.

Creatine phosphokinase was within normal limits. Nerve conductions were normal, and EMG revealed myopathic units. Muscle biopsy, obtained from quadriceps, showed rare central nuclei, type 1 predominance, and relative type 1 hypotrophy (figure, B). Muscle ultrastructure, as determined by electron microscopy, was not obviously disturbed. Genetic testing via a congenital myopathy
Correspondence

Dr. Dowling

james.dowling@sickkids.ca 

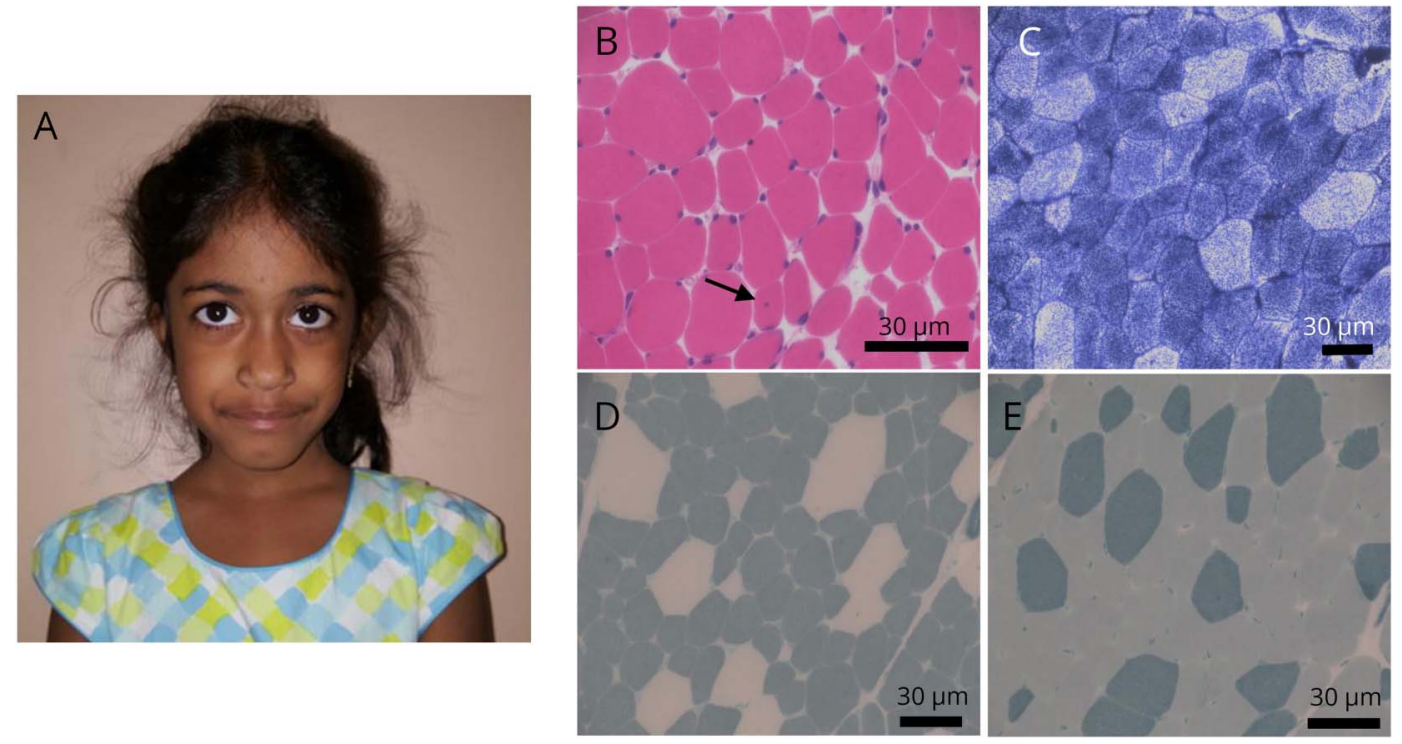

(A) Patient at age 4 years. Note the long and slightly myopathic facies but no clear facial weakness and no restrictions of eye movements. (B-E) Biopsy of the right quadriceps muscle at age 3 years. (B) Hematoxylin and eosin staining showed variability in muscle fiber size and shape and rare fibers with central nuclei (arrow). (C) NADH staining. (D-E) ATPase pH 4.2 (D) and 9.4 (E) staining showed type I predominance and relative type I fiber hypotrophy. Scale bars $=30 \mu \mathrm{m}$. $\mathrm{NADH}=$ nicotinamide adenine dinucleotide.

multigene panel (28 genes, sequencing plus copy number variant testing, University of Chicago) identified a homozygous long interspersed nuclear element (LINE) insertion of approximately 1,250 bps in exon 6 of HACD1 (c.739_740delins1250). Both parents were heterozygous for the mutation.

\section{Discussion}

Here, we present a patient with homozygous mutation in $H A C D 1$, representing only the second case report of HACD1-related congenital myopathy. The clinical phenotype and muscle biopsy findings of our case match the initial report and suggest a condition characterized by initially severe weakness that markedly improves over time and nonspecific muscle pathology most in keeping with congenital fiber-type disproportion.

HACD1 encodes 3-hydroxyacyl-CoA dehydratase, a protein that catalyzes the third step in VLCFA synthesis. VLCFAs are fatty acids with a chain length of $>20$ carbons that function in numerous biological processes, including skin barrier formation, fetal growth, and brain development. There are 4 HACD paralog enzymes responsible for the third step of VLCFA synthesis, ${ }^{4}$ each with differential expression. HACD1 is expressed mainly in the skeletal muscle and heart, ${ }^{5}$ which likely accounts for the muscle-specific presentation in our patient, although cardiac abnormalities were not observed in our case or in the previously reported family. HACD1 has been implicated in myoblast fusion and maintenance of the tubule-reticular system via its ability to regulate membrane phospholipid composition. ${ }^{5,6}$ This may explain the observation of myofiber hypotrophy seen on muscle biopsy. However, neither our case nor the previously reported one exhibits obvious alterations of the tubule-reticular system (i.e., no features of centronuclear myopathy).

The previous $H A C D 1$ pedigree described was a consanguineous family with 8 affected individuals. ${ }^{3}$ Each affected individual had a homozygous nonsense mutation in HACD1 (c.744C >A; p.Tyr248Ter). Functional studies confirmed that this mutation led to loss of HACD1 protein expression. All affected patients presented with a severe phenotype at birth that gradually improved. All patients had reduced muscle tone and proximal weakness, although the oldest patient (aged 35 years) worked as a truck driver with daily heavy lifting without limitation. EMG showed myopathic findings, and muscle biopsy showed decreased type 1 fiber size, increased type 1 fiber number, and rare internally located nuclei. These findings are strikingly similar to our patient and together create a consistent clinical and pathologic phenotype associated with $H A C D 1$ mutation.

Of interest, the mutation mechanism in our patient is a LINE insertion in exon 6. LINE insertion in HACD1 has been described to cause a form of centronuclear myopathy in Labrador retrievers. ${ }^{6,7}$ Clinical features in these dogs include hypotonia, generalized muscle weakness, abnormal posture, stiff hoping gate, and exercise intolerance. Unlike the patients described with HACD1 mutation, however, the affected dogs show progressive clinical features and muscle biopsies with findings of centronuclear myopathy. The explanation for these differences is not known, but most likely relates to 
function variability of HACD1 between species and/or genetic modification.

\section{Study funding}

No targeted funding reported.

\section{Disclosure}

This case report has been contributed to, seen, and approved by all the authors. All the authors fulfill the authorship credit requirements. No honorarium grant or other form of payment was received for the preparation of this case report. $\mathrm{F}$. Al Amrani, C. Gorodetsky, L.-N. Hazrati, K. Amburgey, H.D. Gonorazky, and J.J. Dowling report no disclosures relevant to the manuscript. There is no financial disclosure relevant to this project. Go to Neurology.org/NG for full disclosures.

\section{Publication history}

Received by Neurology: Genetics October 9, 2019. Accepted in final form March 20, 2020.

Appendix Authors

\begin{tabular}{lll}
\hline Name & Location & Contribution \\
\hline $\begin{array}{l}\text { Fatema Al } \\
\text { Amrani, MD }\end{array}$ & $\begin{array}{l}\text { Hospital for } \\
\text { Sick Children }\end{array}$ & $\begin{array}{l}\text { Major role in data acquisition and } \\
\text { codrafted the manuscript }\end{array}$ \\
\hline $\begin{array}{l}\text { Carolina } \\
\text { Gorodetsky, } \\
\text { MD }\end{array}$ & Hospital for & $\begin{array}{l}\text { Acquisition of data and codrafted the } \\
\text { manuscript }\end{array}$ \\
\hline
\end{tabular}

Appendix (continued)

\begin{tabular}{lll}
\hline Name & Location & Contribution \\
\hline $\begin{array}{l}\text { Lili-Naz } \\
\text { Hazrati, MD }\end{array}$ & $\begin{array}{l}\text { Hospital for } \\
\text { Sick Children }\end{array}$ & $\begin{array}{l}\text { Acquisition of data; generation of the } \\
\text { figure; and editorial input on the } \\
\text { manuscript }\end{array}$ \\
\hline $\begin{array}{l}\text { Kimberly } \\
\text { Amburgey, } \\
\text { MSc }\end{array}$ & $\begin{array}{l}\text { Hospital for } \\
\text { Sick Children }\end{array}$ & $\begin{array}{l}\text { Acquisition of data; generation of the } \\
\text { figure; and editorial input on the } \\
\text { manuscript }\end{array}$ \\
$\begin{array}{l}\text { Hernan D. } \\
\text { Gonorazky, } \\
\text { MD }\end{array}$ & $\begin{array}{l}\text { Hospital for } \\
\text { Sick Children }\end{array}$ & $\begin{array}{l}\text { Acquisition and interpretation of data } \\
\text { and editorial input on the manuscript }\end{array}$ \\
\hline $\begin{array}{l}\text { James J. } \\
\text { Dowling, MD, } \\
\text { PhD }\end{array}$ & $\begin{array}{l}\text { Hospital for } \\
\text { Sick Children }\end{array}$ & $\begin{array}{l}\text { Conceived on the study; data } \\
\text { interpretation; and codraft and edit of } \\
\text { the manuscript }\end{array}$ \\
\hline
\end{tabular}

\section{References}

1. Gonorazky HD, Bönnemann CG, Dowling JJ. The genetics of congenital myopathies. Handb Clin Neurol 2018;148:549-564.

2. Gonorazky HD, Dowling JJ, Volpatti JR, Vajsar J. Signs and symptoms in congenital myopathies. Semin Pediatr Neurol 2019;29:3-11.

3. Muhammad E, Reish O, Ohno Y, et al. Congenital myopathy is caused by mutation of HACD1. Hum Mol Genet 2013;22:5229-5236.

4. Ikeda M, Kanao Y, Yamanaka M, et al. Characterization of four mammalian 3-hydroxyacyl-CoA dehydratases involved in very long-chain fatty acid synthesis. FEBS Lett 2008;582:2435-2440.

5. Blondelle J, Ohno Y, Gache V, et al. HACD1, a regulator of membrane composition and fluidity, promotes myoblast fusion and skeletal muscle growth. J Mol Cell Biol 2015;7:429-440.

6. Walmsley GL, Blot S, Venner K, et al. Progressive structural defects in canine centronuclear myopathy indicate a role for HACD1 in maintaining skeletal muscle membrane systems. Am J Pathol 2017;187:441-456.

7. Pele M, Tiret L, Kessler JL, Blot S, Panthier JJ. SINE exonic insertion in the PTPLA gene leads to multiple splicing defects and segregates with the autosomal recessive centronuclear myopathy in dogs. Hum Mol Genet 2005;14:1417-1427. 


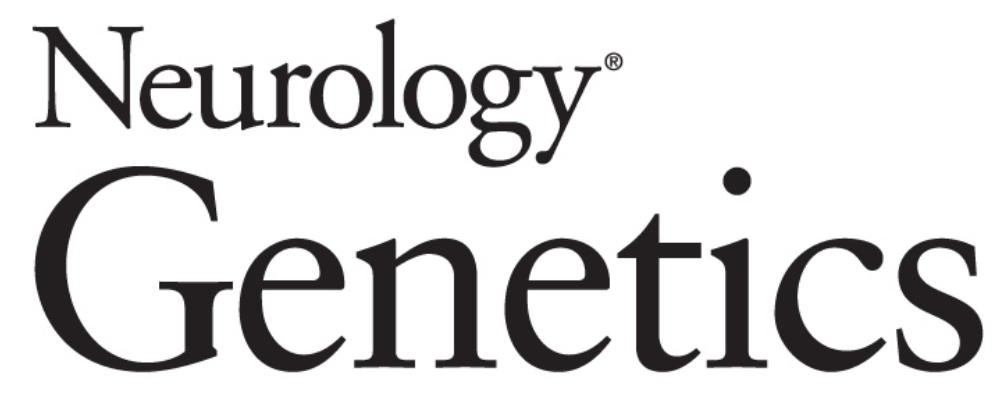

\section{Biallelic LINE insertion mutation in HACD1 causing congenital myopathy Fatema Al Amrani, Carolina Gorodetsky, Lili-Naz Hazrati, et al. Neurol Genet 2020;6; \\ DOI 10.1212/NXG.0000000000000423}

\section{This information is current as of April 13, 2020}

\section{Updated Information \& Services}

\section{References}

Citations

Subspecialty Collections

Permissions \& Licensing

Reprints including high resolution figures, can be found at: http://ng.neurology.org/content/6/3/e423.full.html

This article cites 7 articles, 0 of which you can access for free at: http://ng.neurology.org/content/6/3/e423.full.html\#\#ref-list-1

This article has been cited by 1 HighWire-hosted articles: http://ng.neurology.org/content/6/3/e423.full.html\#\#otherarticles

This article, along with others on similar topics, appears in the following collection(s):

\section{All Genetics}

http://ng.neurology.org//cgi/collection/all_genetics

Developmental disorders

http://ng.neurology.org//cgi/collection/developmental_disorders Muscle disease

http://ng.neurology.org//cgi/collection/muscle_disease

Information about reproducing this article in parts (figures,tables) or in its entirety can be found online at:

http://ng.neurology.org/misc/about.xhtml\#permissions

Information about ordering reprints can be found online: http://ng.neurology.org/misc/addir.xhtml\#reprintsus

Neurol Genet is an official journal of the American Academy of Neurology. Published since April 2015, it is an open-access, online-only, continuous publication journal. Copyright Copyright $\odot 2020$ The Author(s). Published by Wolters Kluwer Health, Inc. on behalf of the American Academy of Neurology.. All rights reserved. Online ISSN: 2376-7839.

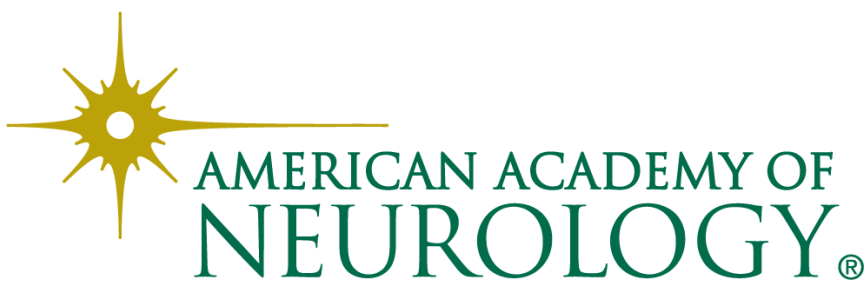

